International Journal of Instruction e-ISSN: 1308-1470 • www.e-iji.net

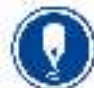

July $2021 \bullet$ Vol.14, No.3

p-ISSN: 1694-609X

pp. 73-94

Article submission code:

20200710212106

Received: 10/07/2020

Revision: 26/11/2020
Accepted: 20/12/2020

OnlineFirst: 08/04/2021

\title{
On the Relationship between Language Learning Strategies and Language Proficiency in Indian Universities
}

\section{Ranjeeva Ranjan}

Dr., Facultad de Educación, Universidad Católica del Maule, Chile, ranjan@ucm.cl

\section{Andrew Philominraj}

Assoc. Prof., Facultad de Educación, Universidad Católica del Maule, Chile, andrew@ucm.cl

\section{Rodrigo Arellano Saavedra}

Facultad de Educación, Universidad Católica del Maule, Chile, rarellano@ucm.cl

Language learning strategies (LLS) research began in the mid-1970s with the main idea of individual differences in learning a foreign language focusing primarily on the characteristics of a good language learner. In the literature review, the use of LLS has been reported to have a positive influence on proficiency. The goal of this research is to examine the relationship between the use of strategies in learning Spanish as a foreign language with its language proficiency and to analyse the use of LLS by successful students. The Strategy Inventory for language learning (SILL) questionnaire and two open-ended questions have been used in the present work for analysing the LLS. Further, the researchers used the end-semester grades to quantify proficiency. The study was carried out at two universities imparting Spanish courses at the undergraduate level. The current study is a mixed-method, cross-sectional, non-experimental type within the descriptive correlational framework. Statistical and interpretive analysis was used to examine self-reported learning strategies. The results showed no relation between the uses of selfreported learning strategies and language proficiency. However, there was a moderate relationship between the use of LLS and proficiency of 15 higher proficient students from both the universities. In the end, the research provides limitations and implications of the current study.

Keywords: language learning strategies, proficiency, Indian universities, foreign language, Spanish

\section{INTRODUCTION}

The focus of research in the field of second language acquisition has been changed in recent decades from teacher-centred instructional learning to learner-centred training keeping in mind the learner's characteristics. Within this change, it is worth mentioning the inquiry in the area of language learning strategies (henceforth LLS) which

Citation: Ranjan, R., Philominraj, A., \& Saavedra, R. A. (2021). On the relationship between language learning strategies and language proficiency in Indian universities. International Journal of Instruction, 14(3), 73-94. https://doi.org/10.29333/iji.2021.1435a 
commenced with the idea of exploring the characteristics of a good language learner and individual differences that occur while learning a language. One of the major challenges in the second language acquisition field concerns the important variations in the linguistic attainments of learners of L2/FL (second/foreign language) in spite of receiving the same quantities and qualities of exposure to the TL (target language). The history of the LLS goes back to the 1970s when the investigation was more aimed at reflecting the characteristics of the successful language learner and the differential success in learning. The seminal work of Rubin (1975) coupled with other research works (Stern, 1975; Hosenfeld, 1976; Naiman et al., 1978) brought the main attention of the researchers to the concept of LLS. Later during the 1980s and 90s, a set of investigation in the LLS arena (Chamot,1987; Wenden \& Rubin, 1987; O'Malley \& Chamot 1990; Oxford, 1990; Grenfell \& Harris, 1999) facilitated this field to expand and advance in the field of second language acquisition and establishing itself as one of the major areas of L2 research (Ellis, 1994). In the new century, the LLS concept has continued to be one of the most researched topics with many volumes (Macaro, 2001; Oxford, 2011, 2017; Griffiths, 2013, 2018; Cohen, 2014; Chamot \& Harris, 2019). Lei and Liu (2019) in their bibliometric analysis on research trends and contributions in applied linguistics found that "learning strategy use" is one of the three dominant themes in the most highly cited articles in "System" a journal of high reputation. In their analysis, they found that the learning strategy used has been one of the "top ten most frequently discussed topics over the 45 years in the field of foreign/second language learning and teaching."

One of the rationales for such enthusiasm in the field of L2 strategy exploration is its "potential of becoming a searchlight (or at least a torch)" for investigating the "black box" (Dörnyei \& Ryan, 2015). Thus, LLS could be used to look inside the brain and provide us with some explanation of this input-output difference while L2 learning. The early research in this field focused primarily on the cognitive aspect of language learning. However, investigation in the LLS field has since evolved and now encompasses the "metacognitive, cognitive, affective and sociocultural dimensions" (Takeuchi, 2019). Two important aspects in the case of research in this field are the psychological and social nature of language learning resulting in the individual variation at the time of learning. Cohen and Griffiths (2015) rightly point out that the research in the field of LLS with cognitive psychology approach "allows for greater reliability and aligns itself with established LLS conceptualizations" whereas investigating LLS from social neo-Vygotskian method "provides higher levels of validity in terms of variability and the complexity of the language learning and language use experience."

During the beginning of this millennium, the LLS field was criticized (Dörnyei \& Skehan, 2003; Dörnyei, 2005; Tseng, Dörnyei, \& Schmitt, 2006). Nevertheless, as Pawlak (2019) appropriately mentions that the inquiry in this field has "never lost its appeal to practitioners, probably on account of the fact that the steps learners take to enhance their language learning are seen as tangible and amenable to pedagogical intervention." 
In this sense, the study of LLS seems relevant due to its establishment as an area of major research inquiry. It is also relevant to highlight its impact on the pedagogical intervention to make the learning experience more fruitful and long-lasting. In a typical Indian foreign language classroom, each student is a distinct individual with his/her own learning pace and with different skills. Students participate in a Spanish language classroom, given their multilingual context and competencies in L1, L2, and L3, wherein they unconsciously develop an aptitude, which can be referred to as translation competence (Ranjan, 2018). In most of the classrooms, the instruction language is English, which plays the role of intermediary due to globalization. The common problems in the language classroom are the heterogeneity of levels, difficulty in controlling all the students, lack of group dynamics, time management, opportunities for intervention, and shortage of attendance.

Given the above reasons, the present study aims to investigate the LLS used by Indian university students in their learning trajectory and examine their relationship with proficiency. The research was conducted amongst the undergraduate students of Spanish at two Central Universities, to examine their self-reported learning strategies, which are used in their learning process. Although there has been some research in the field of LLS in India but is limited to English language learning and hence a lack of research in this field. This exploratory study will serve as a tool for exploring and furthering the research in Strategy Instruction (SI) in the Indian foreign language classrooms in universities. At the societal level, this research has the potential to make Spanish language learning easier, faster, more enjoyable, and more effective by highlighting the explicit and implicit use of LLS in the learning trajectory of university students.

\section{Literature Review}

\section{Definition of LLS}

As per the critics referred to in the introductory section, this literature review part attempts to provide the theoretical underpinnings covering the definition and classification of LLS followed by the previous research on this topic. Since the commencement of research in the field of LLS, an attempt to outline and categorize LLS has always encountered many criticisms. There is no consensus on defining and classifying LLS but many researchers have given their scholarly input regarding the same. Rubin (1975) defines it as "techniques or devices, which a learner may use to acquire knowledge". Stern (1983) termed strategy as "general tendencies or overall characteristics of the approach" employed, more or less, consciously by the language learner. Oxford (1990, p.1) gave a simple explanation of LLS as "steps taken by the students to enhance their own learning". She further complements that strategies are "especially important for language learning because they are tools for active, selfdirected involvement, which is essential for developing communicative competence". Chamot (2004) refers to them as "the conscious thoughts and actions that learners take in order to achieve a learning goal" and points out that the strategic learners possess the metacognitive knowledge about their own thinking and learning approaches. Hence, it is relevant highlighting that consciousness is another important attribute of the strategies. O'Malley \& Chamot (1990) point out the difference between a process, procedure or, 
procedural skill, and strategies. If used frequently, the strategies change to a process or procedural skills and become automatic and unconscious. Therefore, according to them, consciousness forms a fundamental element in the LLS use. Cohen (1998) also claims that conscious selection is essential for the LLS concept because "the element of conscience is what distinguishes strategies from those processes that are not strategic." Griffiths $(2008,2013)$ defined LLS as "activities consciously chosen by learners for the purpose of regulating their own language learning". Recently, Oxford (2017) did a content analysis of 33 existing definitions involving LLS and similar concepts. She itemized the most frequently occurring characteristics of the definitions available previously in the research literature and utilized the results to offer an encompassing and inclusive definition. This new definition also reflects the evolutionary development in the LLS field research and encompasses all the additional concepts introduced during its advancement, which is produced below.

"L2 learning strategies are complex, dynamic thoughts and actions, selected and used by learners with some degree of consciousness in specific contexts in order to regulate multiple aspects of themselves (such as cognitive, emotional, and social) for the purpose of (a) accomplishing language tasks; (b) improving language performance or use; and/or (c) enhancing long-term proficiency. Strategies are mentally guided but may also have physical and therefore observable manifestations. Learners often use strategies flexibly and creatively; combine them in various ways, such as strategy clusters or strategy chains; and orchestrate them to meet learning needs. Strategies are teachable. Learners in their contexts decide which strategies to use. Appropriateness of strategies depends on multiple personal and contextual factors". (p. 48)

\section{Classification of LLS}

The highly argumentative issue of classifying LLS can be perceived since the beginning of the research in the LLS arena. Researchers always face the problem of classifying and categorizing the strategies employed by language students due to several reasons like environmental factors (including the context), unobservable strategies, the individual difference in learning, learner's variables such as age, gender, motivation, etc. Rubin (1981) pointed out two types of learning strategies, which she categorized as direct and indirect. The first one encompasses the strategies, which contribute directly to language learning like clarification/verification, monitoring, memorization, guessing/inductive reasoning, etc. whereas the indirect ones are creating practice opportunities, using production tricks such as using circumlocutions, synonyms, or formulaic interaction. O'Malley et al. (1990) provided a taxonomy with three major types i.e. metacognitive, cognitive, and socio-affective. Oxford (1990), based on Rubin's direct/indirect contrast, furthered the strategy classification into six subdivisions: memory, cognitive, compensation (in the direct category) and metacognitive, affective, and social (in the indirect category). According to Takeuchi (2019), this categorization of Oxford (1990) was a step further in proposing a comprehensive classification system. Cohen et al. (2003) developed their Language Strategy Use Inventory (LSUI) as per language skills. Oxford (2011) came up with another classification system consisting of four categories, which are labelled as cognitive, affective, sociocultural-interactive, and 
"metastrategies," (considering metacognitive strategies). This was done to reduce strategy overlap and "encourage greater theoretical cohesion". Oxford (2017) in her latest book has used the term "role or function" of strategies instead of categories because of the flexibility and fluid nature of the strategies.

\section{Previous Research on this Topic}

In foreign language learning contexts, the LLS may refer to students' choices and behaviours concerning the processes they take up to enhance learning outcomes. The language learning level has shown a strong correlation with learners' choice of strategies (Oxford \& Nyikos 1989). Chamot (2004) also describes this relationship between LLS and the proficiency level of the learners as quite evident. The research studies have shown that more proficient language learners often use LLS more frequently and with a greater variety (Oxford \& Nyikos, 1989; O’Malley \& Chamot, 1990; Green \& Oxford, 1995; Chamot \& El-dinary, 1999; Purdie \& Oliver, 1999; Wharton, 2000; Bruen, 2001; Griffiths, 2003; Anderson, 2005; Hong-Nam \& Leavell, 2006; Psaltou-Joycey \& Kantaridou, 2009; Radwan, 2011; Herrero \& Jiménez, 2014; Martínez et al., 2016). Ever since the study of the "good language learner" in the 1970s, higher language proficiency is found to correlate positively with the frequency of strategy use.

Dreyer \& Oxford (1996), in their investigative study in South Africa on 305 Afrikaans speaking learners, encountered that the SILL strategies strongly predicted strategy proficiency. This proficiency was calculated according to the score in the Test of English as a Foreign Language (TOEFL). In the same study, the use of the metacognitive strategy was the best predictor to explain the variance in the test score. Oxford and Ehrman (1995) in their study found a correlation between the SILL questionnaire and foreign language proficiency. This research work was carried out at the U.S. Foreign Service Institute amongst 262 participants. Herrero \& Jiménez (2014) found that the learners use metacognitive strategies the most in their learning like organizing, planning, and evaluating.

\section{Research Questions}

The research questions of this study are as follows.

1. What is the relationship between LLS use and language proficiency of all the participants, 15 most successful (higher proficient) students, and the rest of the group from the two universities?

2. What is the difference between the usage pattern of LLS by 15 most successful students and the rest of the group from these two universities?

3. Is there any difference in the use of LLS concerning the duration of the study? (year of study)

4. Which aspect of language do the students find most difficult about learning Spanish? Which strategies do they use to help overcome these difficulties?

\section{METHOD}


This research was developed under a mixed-method using a cross-sectional study. It is descriptive, non- experimental, and correlational. The researchers have examined the self-reported LLS with statistical and interpretive analysis. In the current study, to quantify the proficiency, the end-semester grades were used which helped to examine the correlation between proficiency and the LLS use as reported by the participants.

\section{Participants and Research Instruments}

The research was conducted at the undergraduate level, at two central universities having a full-time course in Spanish. Both the universities are important centres as far as the teaching of foreign languages is concerned and the Government of India established one of them to teach a foreign language.

Table 1

Details of participants of the current study

\begin{tabular}{lllll}
\hline Year of study & First Year & Second Year & Third Year & Total \\
\hline EFLU (Hyderabad) & $0^{* * * *}$ & 5 & 14 & 19 \\
\hline JNU (New Delhi) & 19 & 10 & 17 & 46 \\
\hline Total & 19 & 15 & 31 & 65
\end{tabular}

*EFLU: English and Foreign Languages University, Hyderabad

***NU: Jawaharlal Nehru University, New Delhi

**** No admission when the research was carried out.

$33.8 \%$ of the participants were from the first year followed by $18.5 \%$ from the second and $47.7 \%$ from the third. Concerning gender, the sample comprised of 38 female students (58.5\%) and 27 male students $(41.5 \%)$. The age of the students participating in the study varies from 18 to 27 years with an average age of 20.5 for the whole group. In the present study, the researchers have used a questionnaire to collect the data. The questionnaire consisted of three parts, which were divided into Background information questionnaire (BIQ), SILL, and two Open-ended questions.

In this research work, SILL (Strategy Inventory for Language Learning) questionnaire, developed by Oxford (1990) was used, which evaluates the use of language learning strategies. Oxford and Burry-Stock's (1995) research confirmed the predictive validity of the instrument - that it can predict language performance, while Hsiao and Oxford (2002) found that the six-factor classification could better explain learners' strategy use. The practicality of administration (Papadopoulou et al., 2018) is considered to be one of the strongest points of SILL. It is perhaps the most famous instrument (Macaro, 2001), although it is not the only questionnaire of its kind. Mizumoto (2018) in his study on the questionnaire in the LLS field confirmed the popularity of the SILL as the most widely used data collection instrument. This questionnaire has been used extensively for collecting data in research and Amerstorfer (2018) underlines the extension of its purpose, resulting in the attainment of a prominent role in mixed-methods research and small-scale studies, in addition to, its use in large-scale studies (Gavriilidou \& PsaltouJoycey, 2018). There are several other questionnaires designed to evaluate the strategy use, however, this particular questionnaire has more acceptance due to its reliability. 
The SILL questionnaire is divided into two groups: direct and indirect which is further subcategorised into three types each.

Table 2

SILL questionnaire and its component

\begin{tabular}{ll}
\hline Direct strategies & Indirect strategies \\
\hline PART A: Memory (9 items) & PART D: Metacognitive (9 items) \\
\hline PART B: Cognitive (14 items) & PART E: Affective (6 items) \\
\hline PART C: Compensation (6 items) & PART F: Social (6 items) \\
\hline
\end{tabular}

The participants were given the questionnaire and were asked to respond to each item on a Likert scale of five. Apart from this, the end semester grade from both the universities was used to quantify the language proficiency. Some open-ended questions were asked for qualitative analysis. The participants had to answer these questions in the context of their own classroom. The responses received from the participants were transcribed in the excel datasheet for further analysis.

\section{Validation of Instruments}

A pilot test was conducted at the EFLU, Hyderabad with ten third-year students to check, validate, and assess the viability of the processes and to validate the research instruments. Besides, this helped the researchers to evaluate time and resource problems that might occur during the study and avoid any unforeseen problems while researching on a large scale. As the questionnaire was in English, there was no problem in understanding the strategy items and the participants could respond easily on the Likert scale between 1 and 5 .

\section{Data Collection and Ethical Consideration}

The questionnaire was distributed keeping with the practice summarized by Nyikos and Oxford (1993). The goal of the research study was explained to the participating students from the two universities and the questionnaire was completed during class time. During the filling up of the questionnaire, the researcher was present to clarify doubts. The aim was to get the responses of students by reflecting upon their learning process. The survey was carried out in the same way at both universities. The ethical considerations, such as asking for permission and assurance of confidentiality, were taken care of throughout the research process.

\section{FINDINGS AND DISCUSSION}

Data collected from the questionnaire was compiled in excel for further analysis using SPSS software. As a way of strengthening the findings, the results obtained were compared by using different statistical tools such as Spearman's rho correlation and ANOVA.

\section{Cronbach's Alpha}


To check the reliability of the SILL questionnaire and its different subcategories, Cronbach's Alpha test was used. This was substantiated to be very high $(\alpha=.89)$. The reliability score of 0.70 is considered to be standard (Vaus, 1995) and in the present case, it was more than the respectable range (Table 3). However, individual subcategories had fewer reliability scores but were in an acceptable range. Cronbach's Alpha Test result for all the subcategories of the SILL questionnaire is produced below in Table 3.

Table 3

Cronbach's alpha test

\begin{tabular}{lll}
\hline & Cronbach's Alpha & Number of Items \\
\hline SILL (overall) & 0.89 & 50 \\
\hline Memory & 0.65 & 9 \\
\hline Cognitive & 0.74 & 14 \\
\hline Compensation & 0.65 & 6 \\
\hline Metacognitive & 0.84 & 9 \\
\hline Affective & 0.60 & 6 \\
\hline Social & 0.72 & 6 \\
\hline
\end{tabular}

Relationship between LLS and Language Proficiency

Q1. What is the relationship between LLS use and language proficiency of all the participants, of 15 most successful (higher proficient) students, and the rest of the group from the two universities?

The first research question of this study was about the correlation between language proficiency and the use of self-reported LLS for the whole group as well as separately for 15 successful students and the rest of the group. We wanted to examine if there is a correlation between higher proficient students and their use of strategies. Keeping this in mind, we analysed fifteen students from the whole group. These 15 higher proficient students were selected from both the universities based on end semester grade. These 15 successful students were selected from the whole group whose Cumulative Grade Point Average (CGPA) was equal to or greater than 7 (CGPA $\geq 7$ ). Spearman's rho test was used to examine the relationship between the CGPA and the SILL and its six subdivisions. This is a non-parametric test done to see the strength and direction of the monotonic association between two variables.

In Table 4 the correlation between the proficiency CGPA and the usage of different types of language learning strategies is presented. The second column is for all the students from both the universities, the third one is for the 15 successful students and the last one is for the rest of the group leaving the top 15 successful students. 
Table 4

Spearman's rho test between CGPA and SILL and its six subcategories

\begin{tabular}{llll}
\hline Spearman's rho & $\rho /$ all the participants $(\mathrm{r})$ & $\rho /$ top $15\left(\mathrm{r}^{1}\right)$ & $\rho /$ rest of the group $\left(\mathrm{r}^{2}\right)$ \\
\hline CGPA & 1.000 & 1.000 & 1.000 \\
\hline SILL & -.029 & .409 & -.072 \\
\hline Memory & .015 & .280 & -.056 \\
\hline Cognitive & .010 & .245 & -.080 \\
\hline Compensation & -.238 & .426 & -.315 \\
\hline Metacognitive & .133 & .486 & .227 \\
\hline Affective & -.160 & .011 & -.254 \\
\hline Social & .107 & .029 & .102 \\
\hline
\end{tabular}

From Table 4, it is clear that there is a positive weak to moderate relationship between the LLS usage and proficiency for the 15 most successful students from both the universities $\left(\mathrm{r}^{1}=0.409\right)$. Interestingly, two types of strategies, affective, and social strategies are not related to the proficiency reflected by the grades. There is no correlation between CGPA and affective $\left(\mathrm{r}^{1}=0.011\right)$ and social $\left(\mathrm{r}^{1}=0.029\right)$ strategies. However, if we look at the other two columns in Table 4 then we do not find any such relation between LLS use and proficiency. In most of the cases, the coefficient of correlation oscillates between +0.1 to -0.1 . The two categories of strategies, which are positive for all three groups, are metacognitive and social strategies. Within these two, only metacognitive strategies show some weak correlation with language proficiency. In the case of 15 higher proficient students, the metacognitive strategies $\left(r^{1}=0.486\right)$ and compensating strategies $\left(\mathrm{r}^{1}=0.426\right)$ show a moderate positive correlation and memory strategies $\left(\mathrm{r}^{1}=0.280\right)$ a weak correlation with language proficiency. Therefore, it implied that with the increase in the use of metacognitive and compensatory strategies, proficiency also increases moderately.

The research in LLS started with the idea to understand what distinguishes good language learners from less successful ones. Previous research studies conducted on this aspect suggest that more proficient learners tend to use strategies frequently, especially, metacognitive strategies. This usage differs not only in terms of quantity but also in their types. The earlier research studies suggest that proficiency level exercises a significant effect on the overall strategy use as well as on the different categories. The above result (Table 4) was in line with the previous studies mentioned (Al-Buainain, 2010; Alhaisoni, 2012; Hong-Nam \& Leavell, 2006; Feleciya \& Meenakshi, 2016). In all these research studies, the impact of language learning strategy (LLS) use on language proficiency has been found. In the current study, although there was a lack of correlation between the use of strategy and proficiency of Spanish for the whole group ( $\rho /$ all the participants) and the rest of the group ( $\rho /$ rest of the group), the employment of strategies is moderately correlated to the proficiency of the 15 higher proficient students $(\rho /$ top 15). The finding of this part implied that the relationship between overall SILL and proficiency for the high proficient group is moderately positive, which suggests that with the increase in the use of LLS, the proficiency increases moderately. 


\section{Strategy Usage Pattern of the 15 Higher Proficient Students}

Q2. What is the difference between the usage pattern of LLS by 15 most successful students and the rest of the group from these two universities?

The second research question dealt with the pattern of the use of LLS between the highly proficient and less proficient learners. For this purpose, the researchers chose two categories of strategies. The first category consisted of those strategies, which were reportedly being used by the higher proficient participants above the mean of 3 and compared their usage with the rest of the group from both the universities. The second category comprised of those strategies, which were reportedly being used more frequently by the rest of the group and compared them with the higher proficient learners. These two categories have been presented below in Table 5 along with the mean and their standard deviation.

Table 5

Frequently used strategies as reported by the higher proficient group

\begin{tabular}{cllllll}
\hline Sl. No. & \multicolumn{1}{c}{ Learning strategies } & Type & MS & SD & MR & SD \\
\hline 1. & I try to find out how to be a better learner of Spanish. & Meta & 4.27 & 0.80 & 3.64 & 1.22 \\
\hline 2. & I try to learn about the culture of Spanish speakers. & Soc & 4.20 & 0.94 & 3.70 & 1.28 \\
\hline 3. & $\begin{array}{l}\text { If I do not understand something in Spanish, I ask the } \\
\text { other person to slow down or say it again. }\end{array}$ & Soc & 3.93 & 0.80 & 3.66 & 1.24 \\
\hline 4. & $\begin{array}{l}\text { I encourage myself to speak Spanish even when I am } \\
\text { afraid of making a mistake. }\end{array}$ & Aff & 3.87 & 1.06 & 3.64 & 1.24 \\
\hline 5. & $\begin{array}{l}\text { I think of the relationships between what I already know } \\
\text { and the new things I learn in Spanish. }\end{array}$ & Mem & 3.80 & 0.94 & 3.32 & 1.25 \\
\hline 6. & $\begin{array}{l}\text { I find the meaning of a Spanish word by dividing it into } \\
\text { parts that I understand. }\end{array}$ & Cog & 3.80 & 1.32 & 3.06 & 1.19 \\
\hline 7. & I try not to translate word-for-word. & Cog & 3.73 & 1.10 & 2.77 & 1.39 \\
\hline 8. & I try to find patterns in Spanish. & Meta & 3.53 & 0.99 & 3.38 & 1.13 \\
\hline 9. & I have clear goals for improving my Spanish skills. & Comp & 3.27 & 1.49 & 2.74 & 1.28 \\
\hline 10. & I read Spanish without looking up every new word. & & 3.28 & 1.30 \\
\hline
\end{tabular}

MS-Mean of higher proficient learners, MR -Mean of rest of the group, SD-Standard Deviation, Mem (Memory strategies), Cog (Cognitive strategies), Com (Compensation strategies), Met (Metacognitive strategies), Aff (Affective strategies), Soc (Social strategies).

The first strategy from Table 5 belongs to the metacognitive category; "trying to find out how to be a better learner of Spanish" with a significant difference in their usage mean between two groups (MS=4.27, MR=3.64). This indicates, in a way, that higher proficient learners exercise metacognitive control over their learning process. The next strategy is of social subgroup, trying to learn the culture of the target language population (MS1=4.20, MR2 $=3.70$ ). The higher proficient students seem to be more concerned with learning the culture of Spanish speakers. The next strategies are from different subgroups. The proficient group uses the affective strategy of encouraging oneself at the time of being afraid of making a mistake more often when compared to the 
rest of the participants. Encouraging oneself to speak Spanish even when one is afraid of making a mistake by controlling anxiety is the only affective strategy with high use that the proficient group mentioned in their response. This shows that good students are not afraid to take a risk when using Spanish. They can control their affective filters that prevent communication fluently. There is only one strategy from the memory category; thinking of the relationships between what one already knows and new things one learns in Spanish. Contrary to Table 6 where one can see many compensatory strategies being used by the rest of the group, the proficient group reported only one strategy from this category which deals with reading without looking up for every new word. There is a great difference in the use of this particular strategy $(\mathrm{MS}=3.27, \mathrm{MR}=2.74)$. In this list, there is another metacognitive strategy of "having clear goals to improve Spanish skills", which is being used very frequently by this group compared to the rest of the group. This suggests that successful students always use their metacognitive skills and have clarity in their thinking process of how to improve their skills. They also employ various cognitive strategies such as not translating word for word, finding patterns in Spanish, and finding the meaning of a word by dividing it into the comprehensible part (see Table 6).

Table 6

Frequently used strategies as reported by the rest of the participants

\begin{tabular}{|c|c|c|c|c|c|}
\hline Learning strategies & Type & MS & SD & MR & SD \\
\hline $\begin{array}{l}\text { 1. If I cannot think of a Spanish word, I use a word or } \\
\text { phrase that means the same thing. }\end{array}$ & Comp & 3.67 & 1.54 & 4.00 & 1.06 \\
\hline $\begin{array}{l}\text { 2. When I cannot think of a word during a conversation } \\
\text { in Spanish, I use gestures. }\end{array}$ & Comp & 3.07 & 1.22 & 3.32 & 1.20 \\
\hline 3. I use the Spanish word I know in different ways. & $\operatorname{Cog}$ & 3.07 & 1.03 & 3.49 & 1.04 \\
\hline $\begin{array}{l}\text { 4. I try to guess what the other person will say next in } \\
\text { Spanish. }\end{array}$ & Comp & 3.00 & 1.36 & 3.34 & 1.24 \\
\hline $\begin{array}{l}\text { 5. I look for opportunities to read as much as possible in } \\
\text { Spanish. }\end{array}$ & Meta & 2.87 & 1.19 & 3.30 & 1.27 \\
\hline 6. I try to find as many ways as I can to use my Spanish. & Meta & 2.80 & 1.15 & 3.51 & 1.06 \\
\hline $\begin{array}{l}\text { 7. I connect the sound of a Spanish word and an image } \\
\text { or picture of the word to help me remember the word. }\end{array}$ & Mem & 2.67 & 1.05 & 3.40 & 1.15 \\
\hline 8. I read for pleasure in Spanish. & $\mathrm{Cog}$ & 2.40 & 1.18 & 3.15 & 1.37 \\
\hline $\begin{array}{l}\text { 9. I give myself a reward or treat when I do well in } \\
\text { Spanish. }\end{array}$ & Aff & 2.33 & 1.23 & 3.06 & 1.51 \\
\hline $\begin{array}{l}\text { 10. I make up new words if I do not know the right ones } \\
\text { in Spanish. }\end{array}$ & Comp & 2.27 & 1.03 & 3.28 & 1.26 \\
\hline
\end{tabular}

In Table 6, there are four compensatory strategies of direct type like paraphrasing, use of gestures, guessing, and making up of new words if one does not know the right ones. These strategies have been reported being used more frequently by the rest of the group than the higher proficient group. The other strategies pertain to various subcategories. Giving reward to oneself ( $\mathrm{MS}=2.33, \mathrm{MR}=3.06$ ), coining new words ( $\mathrm{MS}=2.27$, $\mathrm{MR}=3.28)$, reading for pleasure $(\mathrm{MS}=2.40, \mathrm{MR}=3.15)$, and trying to find ways to practice Spanish $(\mathrm{MS}=2.80, \mathrm{MR}=3.51)$ are some of the strategies with a significant difference in their usage mean between these two groups. 


\section{The Use of LLS According to the Duration of the Study}

Q3. Is there any difference in the use of LLS concerning the duration of the study? (year of study)

The third question of the research work was about examining the use of LLS according to the duration of the study. Keeping this in mind, the researchers used ANOVA which is used to identify any significant differences between the means of the group when the independent variable (s) is/are nominal (categorical) and when the dependent variable is continuous. ANOVA was used to see if there is a statistically significant difference in the use of strategies between the first, second, and third-year students. The purpose of such a test was to verify and identify any existence of statistically significant effects of the independent variable (in this case the progression of the students) in the use of the learning strategies.

For this purpose, the normality of the data was checked. A Shapiro- Wilk's test $(\mathrm{p}>.05)$ (Shapiro \&Wilk, 1965; Razali \& Wah, 2011) and a visual inspection of their histograms, normal Q-Q plots, and box plots showed that the SILL scores and its subcategories were normally distributed for first, second and third-year students, with the following skewness and kurtosis.

Table 7

Skewness and kurtosis for checking normality of the data

\begin{tabular}{|c|c|c|c|c|}
\hline Year & $\longrightarrow$ & First Year & Second Year & Third Year \\
\hline \multirow[t]{2}{*}{ SILL } & Skewness & $-.266(\mathrm{SE}=.524)$ & $.593(\mathrm{SE}=.661)$ & $-.686(\mathrm{SE}=.441)$ \\
\hline & Kurtosis & $-.343(\mathrm{SE}=1.014)$ & $-.691(\mathrm{SE}=1.279)$ & $1.633(\mathrm{SE}=.858)$ \\
\hline \multirow[t]{2}{*}{ MEM } & Skewness & $.058(\mathrm{SE}=.524)$ & $.479(\mathrm{SE}=.661)$ & $-.053(\mathrm{SE}=.441)$ \\
\hline & Kurtosis & $-.871(\mathrm{SE}=1.014)$ & $-.999(\mathrm{SE}=1.279)$ & $.554(\mathrm{SE}=.858)$ \\
\hline \multirow[t]{2}{*}{$\mathrm{COG}$} & Skewness & $-.050(\mathrm{SE}=.524)$ & $.580(\mathrm{SE}=.661)$ & $-.022(\mathrm{SE}=.441)$ \\
\hline & Kurtosis & $-.829(\mathrm{SE}=1.014)$ & $-.076(\mathrm{SE}=1.279)$ & $.710(\mathrm{SE}=.858)$ \\
\hline \multirow[t]{2}{*}{ COMP } & Skewness & $.651(\mathrm{SE}=.524)$ & $.589(\mathrm{SE}=.661)$ & $.155(\mathrm{SE}=.441)$ \\
\hline & Kurtosis & $-.779(\mathrm{SE}=1.014)$ & $1.082(\mathrm{SE}=1.279)$ & $-.640(\mathrm{SE}=.858)$ \\
\hline \multirow[t]{2}{*}{ META } & Skewness & $.103(\mathrm{SE}=.524)$ & $.464(\mathrm{SE}=.661)$ & $-.482(\mathrm{SE}=.441)$ \\
\hline & Kurtosis & $-.646(\mathrm{SE}=1.014)$ & $-.683(\mathrm{SE}=1.279)$ & $-.078(\mathrm{SE}=.858)$ \\
\hline \multirow[t]{2}{*}{ AFF } & Skewness & $-.049(\mathrm{SE}=.524)$ & $-.316(\mathrm{SE}=.661)$ & $.165(\mathrm{SE}=.441)$ \\
\hline & Kurtosis & $-.562(\mathrm{SE}=1.014)$ & $-.376(\mathrm{SE}=1.279)$ & $-.063(\mathrm{SE}=.858)$ \\
\hline \multirow[t]{2}{*}{ SOC } & Skewness & $.901(\mathrm{SE}=.524)$ & $.543(\mathrm{SE}=.661)$ & $-.435(\mathrm{SE}=.441)$ \\
\hline & Kurtosis & $1.110(\mathrm{SE}=1.014)$ & $-1.000(\mathrm{SE}=1.279)$ & $-.273(\mathrm{SE}=.858)$ \\
\hline
\end{tabular}

After examining the normality of the data, an ANOVA test was carried out. The seven dependent variables in this test included the general use of strategy SILL and the use of strategy for each of the six strategy categories. 
Table 8

ANOVA test

\begin{tabular}{|c|c|c|c|c|c|c|c|}
\hline & & Mean & SD & Min & $\operatorname{Max}$ & $F$ & Sig. (p) \\
\hline \multirow{4}{*}{ SILL (overall) } & First Year & 3.00 & 0.46 & 2.04 & 3.62 & \multirow[t]{4}{*}{4.054} & \multirow[t]{4}{*}{0.02} \\
\hline & Second Year & 3.28 & 0.50 & 2.64 & 4.20 & & \\
\hline & Third Year & 3.39 & 0.46 & 2.10 & 4.26 & & \\
\hline & Total & 3.23 & 0.48 & 2.04 & 4.26 & & \\
\hline \multirow{4}{*}{ Memory } & First Year & 2.74 & 0.55 & 1.89 & 3.66 & \multirow[t]{4}{*}{0.500} & \multirow[t]{4}{*}{0.60} \\
\hline & Second Year & 2.96 & 0.51 & 2.22 & 3.78 & & \\
\hline & Third Year & 2.80 & 0.60 & 1.44 & 4.00 & & \\
\hline & Total & 2.82 & 0.56 & 1.44 & 4.00 & & \\
\hline \multirow{4}{*}{ Cognitive } & First Year & 2.99 & 0.54 & 1.93 & 3.86 & \multirow[t]{4}{*}{3.101} & \multirow[t]{4}{*}{0.05} \\
\hline & Second Year & 3.18 & 0.57 & 2.43 & 4.36 & & \\
\hline & Third Year & 3.42 & 0.61 & 2.07 & 4.79 & & \\
\hline & Total & 3.24 & 0.60 & 1.93 & 4.79 & & \\
\hline \multirow{4}{*}{ Compensation } & First Year & 3.15 & 0.78 & 2.00 & 4.67 & \multirow[t]{4}{*}{0.724} & \multirow[t]{4}{*}{0.49} \\
\hline & Second Year & 3.43 & 0.50 & 2.67 & 4.50 & & \\
\hline & Third Year & 3.35 & 0.66 & 2.33 & 4.83 & & \\
\hline & Total & 3.30 & 0.67 & 2.00 & 4.83 & & \\
\hline \multirow{4}{*}{ Metacognitive } & First Year & 3.18 & 0.65 & 1.89 & 4.22 & \multirow[t]{4}{*}{5.119} & \multirow[t]{4}{*}{0.009} \\
\hline & Second Year & 3.72 & 0.66 & 2.89 & 4.89 & & \\
\hline & Third Year & 3.81 & 0.71 & 2.00 & 4.89 & & \\
\hline & Total & 3.60 & 0.73 & 1.89 & 4.89 & & \\
\hline \multirow{4}{*}{ Affective } & First Year & 2.84 & 0.59 & 1.83 & 3.83 & \multirow[t]{4}{*}{0.850} & \multirow[t]{4}{*}{0.433} \\
\hline & Second Year & 2.86 & 0.64 & 1.67 & 3.83 & & \\
\hline & Third Year & 3.06 & 0.65 & 1.83 & 4.50 & & \\
\hline & Total & 2.95 & 0.63 & 1.67 & 4.50 & & \\
\hline \multirow{4}{*}{ Social } & First Year & 3.12 & 0.41 & 2.50 & 4.16 & \multirow[t]{4}{*}{8.747} & \multirow[t]{4}{*}{0.001} \\
\hline & Second Year & 3.64 & 0.66 & 2.83 & 4.67 & & \\
\hline & Third Year & 3.86 & 0.67 & 2.33 & 5.00 & & \\
\hline & Total & 3.58 & 0.67 & 2.33 & 5.00 & & \\
\hline
\end{tabular}

Table 8 shows that there is a statistically significant difference in the use of learning strategies between the three groups of students (First year, Second year, and Third year) from both the universities. The types of strategies, which have a statistically significant difference in their use, are presented below in Table 9:

Table 9

Strategy category with a value of $\mathrm{p}<0.05$

\begin{tabular}{ll}
\hline STRATEGY CATEGORY & $\mathrm{P}(<0.05)$ \\
\hline SILL (overall) & 0.02 \\
\hline Cognitive & 0.05 \\
\hline Metacognitive & 0.009 \\
\hline Social & 0.001 \\
\hline
\end{tabular}

Table 9 shows that there is a statistically significant difference in the use of these types of strategies by first, second, and third-year students. The p-value in these cases is less 
than 0.05 , which indicates that there is a significant difference in the use of these categories of strategies. A careful observation of Table 8 shows that the third-year students use these strategies more frequently than the second and first-year counterparts. Nonetheless, there is no statistically significant difference in the other three categories of strategies. This result is in line with the previous studies (Magogwe \& Oliver, 2007; Khalil, 2005) where a gradual progression in the LLS use was found with the duration of the study. The overall implication of this part indicated that the repertoire of the learners increases with the duration. It means the more experienced learners (in terms of years of study) use LLS more frequently than the less experienced one. Especially, the metacognitive $(\mathrm{p}=0.009)$ and social strategies $(\mathrm{p}=0.001)$ were found to have the most significant difference in their use when compared with the duration of the study.

The overall implication of the first three quantitative parts indicated that the LLS use is moderately correlated to the higher proficient group, the use of LLS varies according to the proficiency and there is a gradual progression in the repertoire of strategies along with the duration of the study. In the second research question, differences in the use of LLS can be seen between the two groups. The higher proficient group uses metacognitive, cognitive, and social strategies frequently whereas the rest of the group uses strategies that are more compensatory. This is also because the less proficient ones want to make use of other means like gestures, guesses, and paraphrasing during the communication when they lack the vocabulary or correct syntactic structure. The third part implied that the students develop their repertoire of strategies with the duration of study. The current study is in line with the earlier research studies, which have shown that more experienced language learners use more learning strategies (Green \& Oxford, 1995; Oxford \& Burry-Stock, 1995; Wharton, 2000).

\section{Open-ended Questions and their Analysis}

Q4. Which aspect of language do the students find most difficult about learning Spanish? Which strategies do they use to help overcome these difficulties?

The last question was intended to know about the language aspect, such as grammar, vocabulary, meaning, etc., which they find more difficult in learning Spanish and the strategies, which they use to overcome them. Almost $62 \%$ of the students answered that they find the grammar most difficult, followed by vocabulary. About $30 \%$ of the participants reported having difficulty with vocabulary. The responses are presented graphically below (Graph 1). 


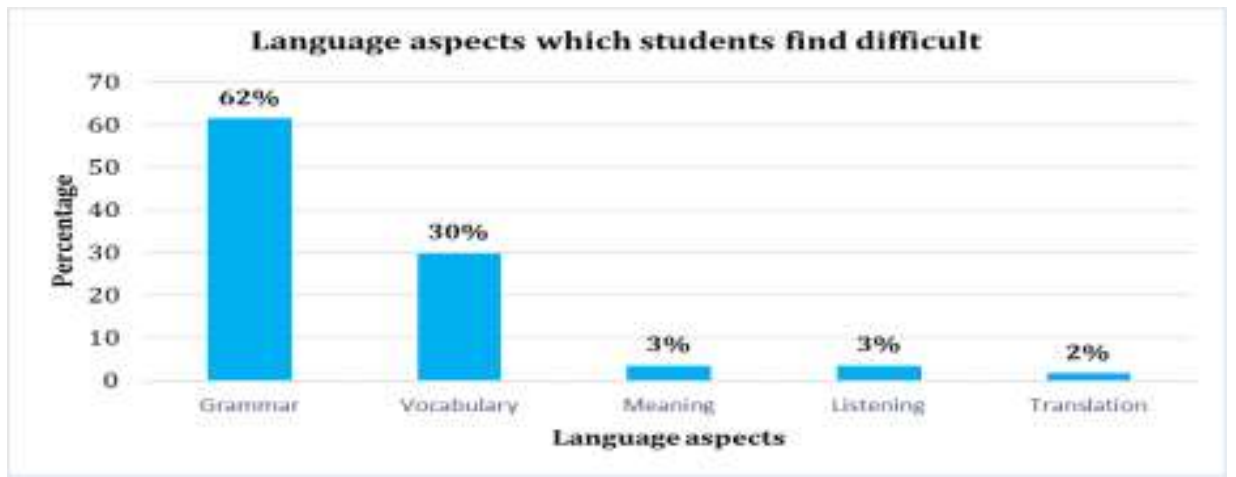

Graph 1

Language aspects which students find difficult

It is not strange to see this result since in most cases the teachers still attach great importance to the grammatical aspects of the language. It should be mentioned here that although teachers do not follow the traditional Grammar-Translation method, it is the students who have internalized the translation pattern due to the multilingual environment in which they grow up. Thus, the teacher must create an environment where students use their own strategies to learn the Spanish language more effectively and efficiently.

The second part of the question was related to LLS used by the participants to help overcome difficulties in the language aspects mentioned above. The responses received were transcribed in the Excel program and then analysed. The result is produced below in the Graph 2.

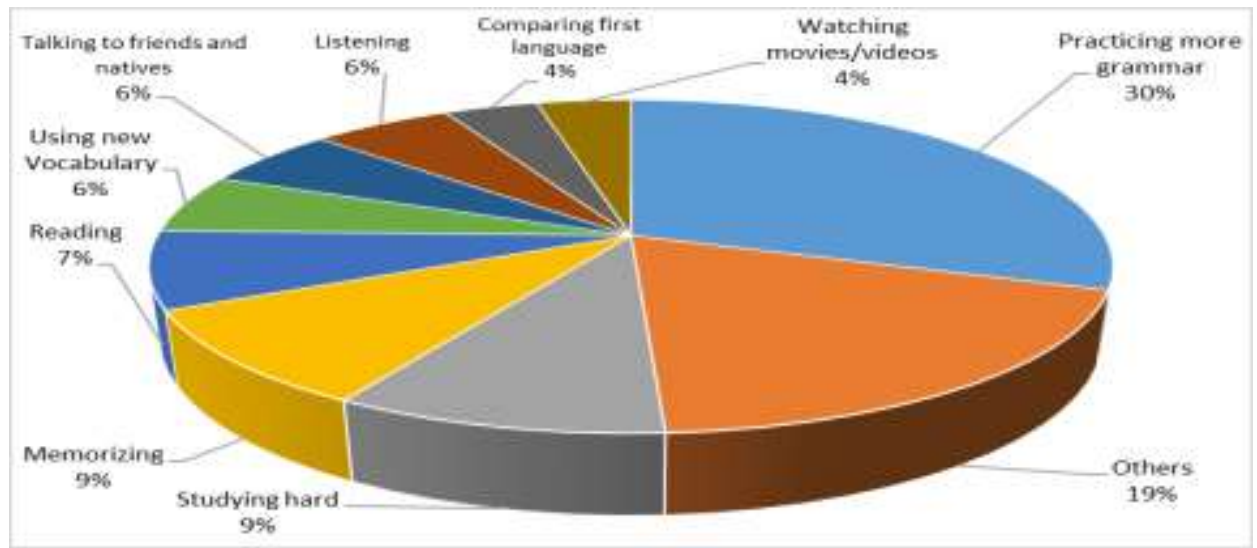

Graph 2

Strategies that students use to overcome difficulties

In Graph 2, one can see that $30 \%$ of the students use practising grammar rules and related exercises as the main strategy to learn Spanish as a foreign language. Other 
reported strategies were studying hard, memorizing, reading, using new vocabulary, talking to friends, listening, and watching movies. These strategies are generic and fall mainly into memory, cognitive and social strategies. One cannot find any metacognitive or affective strategies. This may be because of the lack of strategic training of the learners. In the category of others (19\%), the students gave the following answers (Table 10):

Table 10

Strategies which the participants reported using to overcome difficulties (others)

\begin{tabular}{ll}
\hline 1. & Using a dictionary \\
\hline 2. & Practicing more from online resources \\
\hline 3. & Practical application of Spanish \\
\hline 4. & Writing down important points and then elaborate \\
\hline 5. & $\begin{array}{l}\text { Trying to speak to people who do not know Spanish to gain confidence and get rid of } \\
\text { hesitation }\end{array}$ \\
\hline 6. & Asking questions \\
\hline 7. & Practising translation \\
\hline 8. & Concentrating on the difficulties \\
\hline 9. & Continuous revision \\
\hline 10. & Clarifying doubts and remember synonyms \\
\hline
\end{tabular}

The participants of the current study responded positively regarding learning strategies and their use. Due to their lack of strategic training knowledge, some of the participants stated some other generic tactics such as the ones mentioned above in Table 10. Technology plays an important part in learning a foreign language and thus the response of the students practising more from online resources is coherent. The practical application of Spanish refers to the use of this language in authentic situations. Practising translation is related to the use of grammar as the teachers still follow the traditional grammar-translation method. This is also true because of the translation competence, which the Indian students develop due to the multilingual context in which they develop. If Table 10 is observed, one can find that these are some common approaches, which the participants employ in learning Spanish as a foreign language in India.

\section{CONCLUSION}

The response to the questions raised in this research is summarized in this section. The first question was to examine the relationship between LLS use and language proficiency amongst three groups consisting of: all the participants, 15 most successful (higher proficient) students, and the rest of the group from the two universities. There was no relation between the LLS use and proficiency in the first group of all the participants. However, a moderate positive correlation between the proficiency and LLS use was found for the higher proficient group. There was a lack of correlation between the use of strategy and proficiency of Spanish for the rest of the group (excluding 15 high proficient students from all the participants). The second question dealt with the difference in the usage pattern between two groups: the higher proficient group (Table 5 ) and the rest (Table 6). One can see that the rest of the group of students use 
compensatory strategies (four in the top 10) while the higher proficient group lacks them. They use metacognitive, social, and cognitive strategies more often. This also gives us an idea that they exercise metacognitive schemes in their learning process. The third research question has to do with finding a significant difference in LLS use concerning the duration of the study. It was found that there exists a statistically significant difference in the use of learning strategies between the three groups of students (First, Second and Third year) from both the universities (Table 8 and 9). The most significant difference was found in the use of metacognitive $(p=0.009)$ and social strategies $(\mathrm{p}=0.001)$. Alongside the duration of the study, the findings revealed an increase in the use of LLS. It signifies that there is a gradual progression in the usage of LLS, which increases with the year of study. The last question was qualitative, in which the open-ended questions were used to see the perspectives and attitudes of the participants about the strategies and their use in the process of learning Spanish as a foreign language in the Indian context. This qualitative part, based on the survey, revealed the usage of different types of strategies. For most (62\%), grammar is the most problematic among all aspects of language. That is why most participants reported practising grammar exercises. Two types of strategies have been reportedly used by the majority of students that belonged to the category of visual (cognitive) and social (talk with others).

The participants of the current study responded positively regarding learning strategies and their use. Due to the lack of strategic training, the participants responded with very generic tactics such as practising with the natives and partners, watching movies, practising translations, using the text to improve oral skills, etc. They also responded about the use of modern technology in the classroom, which not only facilitates the learning process in a very significant way but also increases their repertoire of strategies. Although they did not report many other strategies, the answers provided by the participants themselves indicate that they are open to employing strategies in their learning process. The researchers, in their personal experience of teaching, have observed that students practice different types of strategies to facilitate learning, retain information in their memory, and practice the sounds of language.

\section{LIMITATIONS AND IMPLICATIONS OF THE STUDY}

This research work is a mixed-method analysis of the participant's response to their LLS choice but perhaps a more rigorous qualitative analysis (in form of semi-structured interviews) is required to complement this study, to get profound understanding, and to elucidate their selection and usage of these strategies. For evaluating the proficiency, a test could have been conducted. However, the grades were considered in this case, as they would reflect the overall proficiency of the participants in a true sense as the Indian students intend to secure good grades in their exams. Another limitation is the transversal nature of the research work. This study was limited to two universities only but can be replicated to other public and private institutions to ascertain the degree to which the present results could be generalized to other contexts.

The results of this study indicated that the learners of Spanish in India employ LLS frequently in their learning trajectory. The higher proficient group showed a moderate 
positive relationship between their proficiency and the use of LLS. The language teachers can apply the findings in their classroom teaching practices. The researchers can use them to further research in this area. The outcomes of this research have many implications for educational practices in the classroom. Strategy instruction and its application into the language-learning programme can positively influence students' awareness of learning strategies and processes. The integration of strategies in the regular lessons would help in the learning outcomes and the learners should be made aware of the larger repertoire of strategies available as per task demand and contextual suitability.

\section{REFERENCES}

Al-Buainain, H. (2010). Language learning strategies employed by English majors at Qatar University: Questions and queries. ASIATIC, Journal of English Language and Literature, 4(2), 92-120.

Alhaisoni, E. (2012). Language learning strategy use of Saudi EFL students in an intensive English learning context. Asian Social Science, 8(13), 115-127. doi:10.5539/ass.v8n13p115

Amerstorfer, C. M. (2018). Past its expiry date?The SILL in modern mixed-methods strategy research. Studies in Second Language Learning and Teaching, 8(2), 497-523. doi:10.14746/ssllt.2018.8.2.14

Anderson, J. R. (2005). L2 strategy research. En E. Hinkel, Handbook of research in second language research and learning (pp.757-772). New York: Routledge.

Bruen, J. (2001). Strategies for success: Profiling the effective learner of German. Foreign Language Annals, 34(3), 216-225.

Chamot, A. U. (1987). The learning strategies of ESL students. En A. Wenden, \& J. Rubin, Learner strategies in language learning (pp.71-83). London: Prentice Hall.

Chamot, A. U. (2004). Issues in language learning research and teaching. Electronic Journal of Foreign Language Teaching, 1(1), 14-26.

Chamot, A. U., \& El-Dinary, P. B. (1999). Children's learning strategies in immersion classrooms. The Modern Language Journal, 83(3), 319-341.

Chamot, A., \& Harris, V. (2019). Learning strategy instruction in the language classroom: Issues and implementation. Bristol: Multilingual Matters.

Cohen, A. D. (1998). Strategies in Learning and Using a Second Language. London \& New York: Longman.

Cohen, A. D. (2014). Strategies in Learning and Using a Second Language (2nd ed.). New York: Routledge.

Cohen, A. D., Oxford, R., \& Chi, J. C. (2002). Language Strategy Use Inventory. Retrieved from https://carla.umn.edu/maxsa/documents/LanguageStrategyInventory_MAXSA.pdf 
Cohen, A., \& Griffiths, C. (2015). Revisiting LLS research 40 years later. TESOL Quarterly, 53, 414-429.

Dörnyei, Z. (2005). Psychology of the language learner: Individual differences in second language acquisition. Mahwah, NJ: Erlbaum.

Dörnyei, Z., \& Ryan, S. (2015). The psychology of the language learner revisited. New York: Routledge.

Dörnyei, Z., \& Skehan, P. (2003). Individual differences in second language learning. En C. Doughty, \& M. Long, Handbook of second language acquisition (pp.. 589-630). Oxford, UK: Blackwell.

Dreyer, C., \& Oxford, R. (1996). Learning Strategies and other Predictors of ESL Proficiency among Afrikaans-speakers in South Africa. En R. L. (Ed.), Language Learning Strategies Around the World: Cross-cultural Perspectives (pp. 61-74). Manoa: U of Hawaii Press.

Ellis, R. (1994). The study of second language acquisition. Oxford: Oxford University Press.

Feleciya, A., \& Meenakshi, K. (2016). English Language Learning Strategies used by Female ESL Learners of Vellore district-An Empirical Study. Indian Journal of Science and Technology, 9(39). doi:10.17485/ijst/2016/v9i39/98843

García, H. M., \& Jiménez, V. A. (2014). Estrategias en el aprendizaje de la lengua extranjera y niveles de competencia en estudiantes universitarios de magisterio. Revista de Investigación Educativa, 32(2), 363-378. doi:10.6018/rie.32.2.167421

Gavriilidou, Z., \& Psaltou-Joycey, A. (2018). Language learning strategies in Greek primary and secondary school learners: How individual characteristics affect strategy use. En R. L. Oxford, \& C. M. Amerstorfer, Language learning strategies and individual learner characteristics: Situating strategy use in diverse contexts (pp. 167187). London: Bloomsbury.

Green, J. M., \& Oxford, R. L. (1995). A closer look at learning strategies, L2 proficiency, and gender. TESOL Quarterly, 29(2), 261-297.

Grenfell, M., \& Harris, V. (1999). Modern Languages and Learning Strategies: In Theory and Practice. London: Routledge.

Griffiths, C. (2003). Patterns of language learning strategy use. System,, 31, 367-383.

Griffiths, C. (2008). Strategies and good language learners. En C. Griffiths, Lessons from good language learners (pp.. 83-98). Cambridge, UK: Cambridge University Press.

Griffiths, C. (2013). The strategy factor in successful language learning. Bristol, UK: Multilingual Matters. 
Griffiths, C. (2018). The strategy factor in successful language learning: The tornado effect. Bristol: Multilingual Matters.

Hong-Nam, K., \& Leavell, A. (2006). Language learning strategy use of ESL students in an intensive English learning context. System, 34(3), 399-415. doi:10.1016/j.system.2006.02.002

Hosenfeld, C. (1976). Learning about learning: discovering our students' strategies. Foreign Language Annals, 9, 117-129.

Hsaio, T. Y., \& Oxford, R. L. (2002). Comparing theories of language learning strategies:A confirmatory factor analysis. Modern Language Journal, 86(3), 369-383.

Khalil, A. (2005). Assessment of language learning strategies used by Palestinian EFL learners. Foreign Language Annals, 38(1), 108-119.

Lei, L., \& Liu, D. (2019). The research trends and contributions of System's publications over the past four decades (1973-2017): A bibliometric analysis. System, 80, 1-13. doi:10.1016/j.system.2018.10.003

Macaro, E. (2001). Learning Strategies in Foreign and Second Language Classes. London: Continuum.

Magogwe, J., \& Oliver, R. (2007). The relationship between language learning strategies, proficiency, age and self-efficacy beliefs: A study of language learners in Botswana. System, 35(3), 338-352. doi:10.1016/j.system.2007.01.003

Martínez, J., Pérez, M., \& Navarrete, J. (2016). Language learning strategy use by Spanish EFL students: the effect of proficiency level, gender, and motivation. Revista de Investigación Educativa, 34(1), 133-149. doi:10.6018/rie.34.1.232981

Mizumoto, A. (2018). On Questionnaire Use in Language Learning Strategies Research. The Journal of Asia TEFL, 15(1), 184-192. doi:10.18823/asiatefl.2018.15.1.12.184

Naiman, N., Fröhlich, M., Stern, H. H., \& Todesco, A. (1978). The good language learner. Toronto, Canada: Ontario Institute for Studies in Education.

Nyikos, M., \& Oxford, R. (1993). A factor analytic study of language learning strategy use: Interpretations from information processing theory and social psychology. Modern Language Journal, 77(1), 11-22. doi:10.1111/j.1540-4781.1993.tb01940.x

O'Malley, J., \& Chamot, A. (1990). Language learning strategies. Cambridge: Cambridge University Press.

Oxford, R. L. (1990). Language learning strategies: what every teacher should know. New York: Newbury House.

Oxford, R. L. (2017). Teaching and researching language learning strategies. New York: Routledge. 
Oxford, R. L., \& Burry-Stock, J. (1995). Assessing the use of language learning strategies worldwide with the ESL/EFL version of the Strategy Inventory for Language Learning. System, 23(1), 1.23.

Oxford, R., \& Ehrman, M. E. (1995). Adults' Language Learning Strategies in an Intensive Foreign Language Program in the United States. System, 23(3), 359-386. doi:10.1016/0346-251X(95)00023-D

Oxford, R., \& Nyikos, M. (1989). Variables affecting choice of language learning strategies by university students. Modern Language Journal, 73(3), 291-300.

Papadopoulou, I., Kantaridou, Z., Platsidou, M., \& Gavriilidou, Z. (2018). The SILL revisited in light of the $\mathrm{S} 2 \mathrm{R}$ model of language learning. The Language Learning Journal, 46(5), 544-556. doi:10.1080/09571736.2018.1502739

Pawlak, M. (2019). Investigating language learning strategies: Prospects, pitfalls and challenges. Language Teaching Research. doi:10.1177/1362168819876156

Psaltou-Joycey, A., \& Kantaridou, Z. (2009). Plurilingualism, language learning strategy use and learning style preferences. International Journal of Multilingualism, 6(4), 460474.

Purdie, N., \& Oliver, R. (1999). Language learning strategies used by bilingual school aged children. System, 27, 375-388.

Radwan, A. A. (2011). Effects of L2 proficiency and gender on choice of language learning strategies by university students majoring in English. The Asian EFL Journal, 13(1), 114-162.

Ranjan, R. (2018). Language Learning Strategies: Its role in learning of Spanish in Indian Universities. Proceedings Vth International Conference on Language, Society and Culture in Asian Contexts (LSCAC 2018) (pp. 1510-1521). Malang, Indonesia: Media Nusa Creative.

Razali, N. M., \& Wah, Y. B. (2011). Power Comparisons of Shapiro-Wilk, Kolmogorov-Smirnov, Lilliefors and Anderson-Darling Tests. Journal of Statistical Modeling and Anlytics, 2, 21-33.

Rubin, J. (1975). What the "Good Language Learner" Can Teach Us. TESOL Quarterly, 9(1), 41-51.

Rubin, J. (1981). Study of cognitive processes in second language learning. Applied Linguistics, 2(2), 117-131. doi:10.1093/applin/II.2.117

Shapiro, S., \& Wilk, M. (1965). An Analysis of Variance Test for Normality (Complete Samples). Biometrika, 52(3/4), 591-611. doi:10.2307/2333709

Stern, H. (1983). Fundamental Concepts of Language Teaching: Historical and Interdisciplinary Perspectives on Applied Linguistic Research. Oxford: Oxford University Press. 
Stern, H. H. (1975). What can we learn from the good language learner? Canadian Modern Language Review, 34, 304-318.

Takeuchi, O. (2019). Language Learning Strategies: Insights from the Past and Directions for the Future. En Gao, Second Handbook of English Language Teaching. Springer International Handbooks of Education. Springer.

Tseng, W.-T., Dörnyei, Z., \& Schmitt, N. (2006). A new approach to assessing strategic learning: The case of self-regulation in vocabulary acquisition. Applied Linguistics, 27(1), 78-102.

Vaus, D. (1995). Surveys in Social Research. Sydney: Allen \& Unwin.

Wenden, A., \& Rubin, J. (1987). Learner strategies in language learning. Englewood Cliffs, NJ: Prentice Hall.

Wharton, G. (2000). Language Learning Strategy Use of Bilingual Foreign Language Learners in Singapore. Language learning, 50(2), 203-243. 